\begin{tabular}{|c|c|c|c|}
\hline Article Info & RESEARCH ARTICLE & ARAŞTIRMA MAKALESİ & \\
\hline Title of Article & \multicolumn{2}{|c|}{$\begin{array}{l}\text { Zero Waste Management, A Case Study for } \\
\text { Marmara University, Anadoluhisarı Campus }\end{array}$} & \\
\hline $\begin{array}{l}\text { Corresponding } \\
\text { Author }\end{array}$ & \multicolumn{2}{|c|}{$\begin{array}{l}\text { Betül Hande GÜRSOY HAKSEVENLER } \\
\text { Marmara Üniversitesi, Siyasal Bilgiler Fakültesi, Kamu Yönetimi Bölümü, 34820, } \\
\text { İstanbul, TÜRKIYYE, hande.gursoy@ marmara.edu.tr }\end{array}$} & \\
\hline $\begin{array}{l}\text { Received Date } \\
\text { Accepted Date }\end{array}$ & \multicolumn{2}{|l|}{$\begin{array}{l}23.09 .2020 \\
17.12 .2020\end{array}$} & \\
\hline Author / Authors & $\begin{array}{l}\text { Betül Hande GÜRSOY HAKSEVENLER } \\
\text { Fatma Feyza KAVAK } \\
\text { Aydin AKPINAR }\end{array}$ & $\begin{array}{l}\text { ORCID: 0000-0003-3711-5058 } \\
\text { ORCID: 0000-0003-3831-8420 } \\
\text { ORCID: } 0000-0002-7392-6205\end{array}$ & \\
\hline How to Cite & \multicolumn{2}{|c|}{$\begin{array}{l}\text { Gürsoy Haksevenler B., Kavak F.F., Akpınar A., (2020) Sıfır Atık Yönetimi, } \\
\text { Marmara Üniversitesi Anadoluhisarı Kampüsü Örneği, Kent Akademisi Dergisi, } \\
\text { Volume, 13, Issue 4, Pages, 722-735 }\end{array}$} & $\begin{array}{l}\text { Kent Akademisi } \\
\text { Urban Academy }\end{array}$ \\
\hline
\end{tabular}

\title{
Sıfır Atık Yönetimi, Marmara Üniversitesi Anadoluhisarı Kampüsü Örneği
}

\section{Betül Hande GÜRSOY HAKSEVENLER ${ }^{1}$ Fatma Feyza KAVAK ${ }^{2}$ Aydın AKPINAR ${ }^{3}$}

\begin{abstract}
:
In this study, which is about the implementation of Zero Waste Management (ZWM) in Marmara University Anadoluhisar1 Campus, it is aimed to shed light on the question of to what extent the understanding of zero waste management can be realized in our country. In addition to the recycling of waste to the economy, it was targeted to reveal out how the highly educated individuals of the society, namely students, can adopt this practice. In this context, the method followed in the study was i) determination of the current situation (determining where and how much waste was generated in the current situation and how it was disposed of), ii) waste segregation and reduction studies and iii) awareness measurement. In the light of the findings obtained, the amount of waste collected in the campus was $193.20 \mathrm{~g} /$ person.day before the implementation of ZWM. After applying ZWM, the amount of waste collected was increased to $295.54 \mathrm{~g} /$ person.day. While all of the wastes $(100 \%)$ were non-recyclable before the ZWM application, $69 \%$ of the waste was separated as recyclable waste and the amount of non-recyclable waste was reduced to $31 \%$. The recyclable waste collected throughout the campus was composed of $9 \%$ glass, $11 \%$ paper, $35 \%$ metal/plastic, $14 \%$ organic waste. As a result of the survey study, it was determined that the students did not sufficiently notice the ZWM application in the campus and the campus stakeholders did not have sufficient sensitivity about this issue. According to the results of the survey, it was necessary to increase the information and guidance activities about the ZWM application in the campus.
\end{abstract}

\footnotetext{
${ }^{1}$ Marmara Üniversitesi, Siyasal Bilgiler Fakültesi, Kamu Yönetimi Bölümü, hande.gursoy@ marmara.edu.tr

${ }^{2}$ Marmara Üniversitesi, Sosyal Bilimler Enstitüsü, Siyaset Bilimi ve Kamu Yönetimi Anabilim Dalı, fatmafeyzakavak@gmail.com

${ }^{3}$ Marmara Üniversitesi, Siyasal Bilgiler Fakültesi, Yerel Yönetimler Bölümü, aydin.akpinar@ marmara.edu.tr
} 
KEYWORDS: Awareness Research, University Campus, Zero Waste Management, Waste Categorization, Waste Reduction

ÖZ:

Marmara Üniversitesi Anadoluhisarı Kampüsü'nde Sıfır Atık Yönetimi (SAY) uygulanması konu edinilen bu çalışmada, ülkemizde sıfır atık yönetimi anlayışının ne ölçüde gerçekleştirilebileceği sorusuna 1şık tutulması hedeflenmiştir. Atığın ekonomiye kazandırılmasının yanı sıra özellikle toplumun yetişmekte olan bireylerinin, diğer bir ifadeyle öğrencilerin bu uygulamayı ne ölçüde benimseyebileceklerinin araştııılması yapılmıştır. Bu kapsamda çalışmada izlenen yöntem, i) mevcut durumun tespiti (mevcut durumda nereden, ne miktarda atık oluştuğu ve bunun ne şekilde bertaraf edildiğinin belirlenmesi), ii) atık ayrıştırma ve azaltma çalışmaları ve iii) farkındalık ölçümü şeklinde olmuştur. Elde edilen bulgular 1şı̆ı̆ında, kampüste toplanan atık miktarı 193,20 gr/kişi.gün iken, mevcut çalışmanın gerçekleştirilmesi ile birlikte toplanan atık miktarı 295,54 gr/kişi.gün olmuştur. SAY uygulamasından önce atıkların tamamı dönüştürülemeyen atık niteliğinde iken uygulama ile birlikte, dönüştürülebilir atık olarak \%69'luk kısım ayrılmış, dönüştürülemeyen atık miktarı \%31'e indirilmiștir. Kampüs genelinde toplanan ayrık atığın \%9'unu cam, \%11'ini kâğıt, \%35'ini metal/plastik, \%14'ünü organik atık oluşturmaktadır. Farkındalık ölçme adımı olan anket çalışması sonucunda öğrencilerin kampüsteki SAY uygulamasını yeterince fark etmedikleri ve kampüs paydaşlarının bu konu hakkındaki yeterli duyarlılı̆ga sahip olmadıkları belirlenmiş̧ir. Anket sonuçlarına göre kampüs içerisinde SAY uygulaması hakkında bilgilendirme ve yönlendirme faaliyetlerinin arttırılması gerekmektedir.

ANAHTAR KELIMELER: Atık Azaltımı, Atık Kategorizasyonu, Farkındalık Araştırması, Sıfır Atık Yönetimi, Üniversite Kampüsü

\section{GİRiş:}

Ülkemizde hızlı nüfus artışı ve tüketim alışkanlıklarının değişmesi ile oluşan atık miktarı artış göstermektedir. Bu durum atıkların sürdürülebilir ve entegre yönetiminin gerekliliği ihtiyacını ortaya çıkarmıştır. Sürdürülebilir atık yönetimi; atığın oluşumunun önlenmesi, oluşan atıkların tekrar kullanması, geri dönüştürülmesi ve geri kazanılması süreçlerini kapsayan bir atık yönetim planı hazırlanmasını gerekli kılmaktadır. Atıkların bertarafında geri dönüşüm ve geri kazanım süreçleri dikkate alınmadığında hem hammadde hem de enerji olarak önemli kaynaklar kaybedilmektedir. Bugün atık yönetiminde sıklıkla gündemimize gelen Sıfır Atık Yönetimi (SAY), söz konusu kaynak kayıplarının önüne geçmek üzere üretim sonucu ortaya çıkan atıkların tekrar değerlendirilmesi ve atık oluşum sebeplerinin gözden geçirilerek atığın oluşum esnasında önlenmesini temel alan bir atık yönetim politikası olarak karşımıza çıkmaktadır (Cheremisinoff, 2003).

Atık yönetimi yalnız ülkemiz için değil, tüm dünya için önemli bir konudur. Ancak ülkemizde konunun öneminin nispeten geç fark edilişi, atılan adımların gelişmiş ülkelere kıyasla geriden gelmesine sebep olmuştur. SAY'ın özünü oluşturan geri kazanım anlayışında Almanya \%56, Avusturya ve Güney Kore \%54 değerleri ile öncü ülkeler olarak sıralanmaktadır (Gray, 2017). Ülkemizdeki kentsel atıkların geri kazanım oranı ise $\% 6$ seviyelerinde olup, Çevre ve Şehircilik Bakanlı̆̆g'nın 2023 yılı hedeflerinde bu değerin \%35'e yükseltilmesi planlanmaktadır (ÇŞB, 2017). Türkiye'de ortaya çıkan atığın \%87'sini belediye atıkları, kalan \%13'ünü tehlikeli atık, tıbbi atık, özel atık ve ambalaj atığı oluşturmaktadır (ÇŞB, 2017). Belediye atıklarının önemli bir kısmını ise organik atıklar (\%56), kâğıt-karton (\%8), plastik (\%6), cam (\%3) ve metal (\%1) olmak üzere geri dönüştürülebilir atıklar oluşturmaktadır, bunların dışında kalanlar yanabilir nitelikte olanlar (\%17), evsel tehlikeli sınıfında olanlar (\%1) ve diğer atıklardır (\%8) (ÇŞB, 2017). TÜİK'in 2018 yılı verilerine göre ülkemizde kişi başına toplanan günlük atık miktarı $1,16 \mathrm{~kg} / \mathrm{kişi.gün,}$ belediyelerden toplanan toplam yıllık atık miktarı ise 32,2 milyon ton/yıl olarak belirlenmiştir. Belediyeler tarafından toplanan bu atı̆̆ın \%67'si düzenli depolama tesislerinde, $\% 20$ 'si düzensiz depolama alanlarında bertaraf edilmektedir. Atığın geri kalanı geri kazanım tesislerine gönderilmekte (\%12) ve açıkta yakılarak, gömülerek ve/veya dereye/araziye dökülerek uzaklaştırılmaktadır (<\%1) (TÜİK, 2019). 
Görüldüğü üzere ülkemizde belediye atıkları içindeki geri dönüştürülebilir atık miktarı yüksek olmakla birlikte mevcut bertaraf yöntemleri ile bu atıkların çoğu geri dönüşüme ve/veya geri kazanıma kazandırılamamaktadır. Bu durumun önüne geçmek üzere 12.07.2019 tarihinde "Sıfır Atık Yönetmeliği (RG: 30829)" yayımlanmıştır. Yönetmelikle atık oluşumunun önlenmesi, önlemenin mümkün olmaması durumunda ise atığın en aza indirilmesi, yeniden kullanıma öncelik verilmesi, kaynakların verimli kullanılması, atığın kaynağında ayrı toplanması, etkin toplama sisteminin kurulması ve atıkların geri dönüşümü/geri kazanımının sağlanması amaçlanmıştır. Yönetmeliğin uygulanmasıyla geri kazanım anlayışı mahalli idarelerde, kamu kurum ve kuruluşlarında, sanayi bölgelerinde ve belirli sanayi tesislerinde, eğitim kurumlarında, sağlık kuruluşlarında, iş merkezlerinde ve alışveriş merkezlerinde, konaklama tesisleri ve akaryakıt istasyonlarında mecburi hale gelmektedir (ÇŞB, 2019). Bu kapsamda SAY yaklaşımı yalnızca atığı geri kazanmak, geri dönüştürmek ve/veya enerji elde etmek olarak anlaşılmamalı, bunun yerine atığı hiç üretmeden veya yeniden kullanabilecek şekilde kullanmak/üretmek olmalıdır. Atık üretimindeki temel sebebin tüketim olduğu dikkate alındığında, tüketim alışkanlıklarımızın günlük yaşantımızda değişmesi gerekli görülmektedir. Bireylerin çevrenin korunmasına yönelik kazandıkları olumlu davranışlar ailede başlayıp, eğitim kurumlarında pekişmektedir. Çevrenin korunmasına yönelik eğitim ne kadar erken yaşta başlarsa, o kadar çok benimsenecektir. Ancak eğitim kurumları içinde en yetişmiş/yetișmekte olan bireylerin yer aldıkları üniversiteler, yüksek nüfusta öğrenci barındırmaları ve farklı ölçeklerdeki kentsel ve bilimsel faaliyetleri nedeni ile "küçük kentler" olarak değerlendirilmektedir (Adeniran ve ark., 2017). Burada yetişen bireylerin gelecekte kurumlarda yönlendirici/yönetici olacağı ve yeni nesillerin yetişmesinde rol alacakları dikkate alındığında, çevrenin sürdürülebilirliği konusunda günümüz ve gelecek için önem taşımaktadır.

Ülkemizde atık yönetimi ile ilgili çalışmalar incelendiğinde, Türkiye geneli için ulusal düzenlemeler ve uygulama sonuçlarını içeren çalışmalar (Köse ve ark., 2007; Akdoğan ve Güleç, 2007; Öztürk, 2010; Büyükbektaş ve Varınca, 2008; Dönmez ve Değirmen; 2016) olduğu gibi İstanbul (Karakaya, 2008; Yıldız ve ark., 2009), İzmir (Palabıyık, 2001), Kütahya (Yılmaz ve Bozkurt, 2010), İstanbul-Kadıköy ilçesi (Ulaşl1, 2018) gibi bölgeler özelinde çalışmalar olduğu da gözlenmektedir. Atık yönetimini konu alan tezler araştırıldığında SAY'ın kamu kurumlarında ve işletmelerde uygulanabilirliğine ilişkin çalışmaların son yıllarda arttığı görülmektedir. Bu çalışmalara örnek olmak üzere Adana Çevre Şehircilik İl Müdürlüğü (Demir, 2019), Tekirdağ Süleymanpaşa Belediyesi idari binaları (Erdur, 2019), Niğde Belediyesi Binası (Bilgin, 2020), Antalya'da beş yıldızlı bir otel işletmesi (Büyükkol, 2019) ve Kayseri Şehir Hastanesi (Karaman, 2019) üzerine yapılan çalışmaları göstermek mümkündür. Çalışmamızda konu alındığı gibi üniversitelerde de sıfır atık yönetimine/atık yönetimine ilişkin çalışmalar mevcuttur. Gül (2019) tarafindan gerçekleştirilen çalışmada Namık Kemal Üniversitesi Çorlu Mühendislik Fakültesi'nde SAY uygulanarak toplanan atık miktarı ve genel dönüşüm potansiyeli araştırılmıştır (Gül, 2019). Akın (2020) tarafından Erciyes Üniversitesinde SAY uygulanmış ve daha etkin hale getirilebilmesi için SWOT analizi yapılmış ayrıca yeşil kampüs ve sürdürülebilirlik kavramlarını esas alan GreenMetric sıralamaları değerlendirilmiştir (Akın, 2020). Okutan (2017)'ın Boğaziçi Üniversitesi'nde gerçekleştirdiği çalışmada, atık yönetimine ilişkin faaliyetlerin başarılı olabilmesi ve şehir genelinde uygulanabilmesi için eğitim seviyesi yüksek bireylerde çevre bilincinin kolayca kazandırılabileceği sonucuna ulaşarak yeşil kampüs çalışmaları gerçekleştirilmiştir. Ömürbek ve ark. (2019) tarafından yapılan bir çalışmada ülkemizdeki üniversitelerin atık yönetimine ilişkin izlediği politikalar incelenmiştir. Devlet ve vakıf üniversiteleri içerisinde toplamda 52 üniversitede atık yönetimine ilişkin çalışmalar yürütüldüğü ancak web sayfalarında bilgilendirmeye yönelik verilere ulaşmanın zor olduğu sonucuna ulaşılmıştır. Bahçelioğlu ve ark. (2020), Ortadoğu Teknik Üniversitesinde yaptıkları bir çalışmada kampüs içindeki atıkların geri dönüştürülebilirliğini araştırmış ve toplam atığın \%13'ü geri dönüştürülebilmiştir. Ferronato ve ark. (2017) gelişmiş ve gelişmekte olan ülkelere ait yüksek eğitim kurumlarında katı atık yönetimine yaklaşımın ne şekilde değişebildiğini uygulanan anketler üzerinden incelenmiştir. Gelişmekte olan ülkedeki yüksek eğitim kurumundan elde edilen sonuçlarda öğrencilerin atık ayrımından haberdar olmadıkları ve bu konuda bilinçli de olmadıkları belirlenmiştir (Ferronato ve ark., 2017). Martinez ve Barrios (2020) Meksika'nın Cuernavaca kentinde sivil toplum kuruluşları aracıllğıyla Meksika Ulusal Özerk Üniversitesi'nde sürdürülebilirliğin etkin kılınması için bir taban inovasyon analizi gerçekleştirilmiştir. Çalışmada SAY'ın taban inovasyon olduğu ve sürdürülebilirlik açısından üniversitenin büyük önem taşıdığı sonucuna ulaşılmıştır. Üniversitelerde atık ayrımını konu alan çalışmalarda kampüslerde atık geri dönüşüm uygulamalarının diğer kurumlara göre nispeten ekonomik ve kolay yapılabilir olduğu sonucuna varılmıştır. Yapılan çalışmalarda atık geri dönüşüm oranı, Tanzanya'da üç farklı üniversite kampüsünde \%71-86 (Mbuligwe, 2002); Meksika'da bir üniversitede \%65 (Armijo de Vega ve ark., 2008); Kanada'da bir üniversitede \%70 (Smyth ve ark, 2010); Malezya'da bir üniversitede \%80 oranında (Malakahmad ve ark., 2010) bulunmuştur.

Ülkemizde yakın zamanda yayımlanarak yürürlüğe giren Sıfır Atık Yönetmeliğinin Ek-1'inde mahalli idareler ile bina ve yerleşkeler için SAY sisteme geçişleri için son tarihler verilmiştir. Bu çalışmada odaklanılan üniversiteleri de 
ilgilendirecek şekilde " 250 ve fazla öğrencisi bulunan eğitim kurumları" için sisteme geçişlerinin son tarihi 31.12.2020 olarak belirlenmiştir (ÇŞB, 2019). Bu ifadeye göre 31.12.2020 tarihinden itibaren üniversitelerde oluşan atıkların düzenli bir şekilde ayrıştırılması zorunlu hale getirilecektir. Buna bağlı olarak, İstanbul İl Çevre Müdürlüğü aracılığıyla Marmara Üniversitesi ve Cerrahpaşa Üniversitesi pilot üniversiteler olarak seçilmiştir. Mevcut çalışma bu yasal zorunluluk öncesinde (Haziran 2018) Marmara Üniversitesi Anadoluhisarı Kampüsü’nde başlamış, çalışma ile SAY anlayışının ne ölçüde gerçekleştirilebileceği sorusuna ışık tutulması hedeflenmiştir. Bu amaçla önce kampüs içinde toplanan atık kaynakları ve miktarları belirlenmiş, ardından SAY sistemi uygulanarak atığın bina içinde ve dışında kâğıt, metal/plastik, cam ve geri dönüşemeyen atık olarak ayrı toplanması sağlanmıştır. Ayrıca üniversite kampüsü sınırları içerisinde öğrencilerin SAY'ın ne ölçüde farkında olduklarını belirlemek amacıyla öğrencilere anket uygulanmıştır. Bu çalışmanın temelini oluşturan sıfır atık yönetimi yeni ve güncel bir konu olması nedeniyle her geçen gün literatürde daha fazla yerini almaktadır. Çalışmanın gerçekleştirildiği dönem (2018-2020) itibariyle bu konuyu doğrudan ele alan sınırlı sayıda ulusal makale ve tez bulunmaktadır. Uzun dönemli bir gözlem sürecinin sonuçlarını paylaşan bu çalışmada SAY'ın mevcut durumda kampüse ve çevreye olumlu katkısı bilimsel verilerle sunulmaktadır. Bunun yanı sıra uygulamayı sosyal yönü ile ele alarak geleceğe dair yine bilimsel tespitler yapması itibariyle literatüre özgün bir katkı yapması ve elde edilen sonuçların yüksek eğitim kurumlarındaki politika yapıcıları için bir rehber nitelikte olabileceği düşünülmektedir.

\section{MATERYAL VE METOD:}

\section{1. Çalıșma Sahası Bilgileri}

Çalışma kapsamında gerçekleştirilen SAY uygulaması, Marmara Üniversitesi’nin yedi kampüsünden biri olup, $121.991 \mathrm{~m}^{2}$ büyüklüğe sahip olan Anadoluhisarı Kampüsü içinde yapılmıştır. Kampüste Siyasal Bilgiler Fakültesi, Sosyal Bilimler Meslek Yüksekokulu (MYO) ve Spor Bilimleri Fakültesi ile personel ve öğrenci yemekhaneleri bulunmaktadır. Sistemin kurulması ve uygulanır hale gelmesinin takibine ilişkin çalışmalar 07.11.2018 - 22.11.2018, 24.05.2019 - 14.06.2019 ile 21.10.2019 - 01.11.2019 dönemlerinde eş zamanlı olarak yapılmıştır. Çalışmanın yapıldığı birimlere ait bilgiler Tablo 1'de açılanmıştır. Çalışmanın gerçekleştiği dönemde kampüste yer alan kantin kapalı olup, kantinden çıkabilecek olası atıklar değerlendirmeye alınamamıştır.

Tablo 1. Kampüste Yer Alan Birimler ve Özellikleri

\begin{tabular}{|c|c|c|c|c|c|c|}
\hline Kampüsteki Birimler & $\begin{array}{l}\text { Alanı } \\
\left(\mathbf{m}^{2}\right)\end{array}$ & $\begin{array}{l}\text { Öğrenci } \\
\text { Sayısı }\end{array}$ & $\begin{array}{l}\text { Aktif } \\
\text { Öğrenci } \\
\text { Sayısı* }\end{array}$ & $\begin{array}{c}\text { Akademik } \\
\text { Personel } \\
\text { Sayısı }\end{array}$ & $\begin{array}{l}\text { İdari Personel } \\
\text { Sayısı }\end{array}$ & Atık Oluşması Beklenen Noktalar \\
\hline Siyasal Bilgiler Fakültesi & 1500 & 1700 & 500 & 110 & 18 & $\begin{array}{l}\text { Sinıflar, ofisler, fotokopi odaları, } \\
\text { tuvaletler, çay ocakları }\end{array}$ \\
\hline Spor Bilimleri Fakültesi** & 3500 & 1782 & 550 & 36 & 19 & $\begin{array}{l}\text { Spor salonu, havuz, sınıflar, ofisler, } \\
\text { fotokopi odaları, tuvaletler, çay } \\
\text { ocakları, kütüphane }\end{array}$ \\
\hline Sosyal Bilimler MYO & 1500 & 3186 & 550 & 62 & 12 & $\begin{array}{l}\text { Sınıflar, ofisler, fotokopi odaları, } \\
\text { tuvaletler, çay ocakları }\end{array}$ \\
\hline Öğrenci Yemekhanesi & 200 & - & 350 & - & - & Yemekhanenin kendisi \\
\hline $\begin{array}{l}\text { Akademik ve İdari Personel } \\
\text { Yemekhanesi }\end{array}$ & 50 & - & - & 50 & 10 & Yemekhanenin kendisi \\
\hline
\end{tabular}

\subsection{SAY Uygulaması Öncesinde ve Sonrasında Atık Miktarının Belirlenmesi}

Çalışmada ilk adım olarak binaların içerisinde oluşan atık türleri ve miktarları belirlenmiştir. Ardından oluşan atıkların kaynakları tespit edilmiş̧ir. Atıkların kaynaklarında ayrıştırılması ve ayrı toplanması için her üç bina ve yemekhane içinde atı̆̆ın ayrı toplanabileceği atık toplama noktaları belirlenmiştir. Bina içlerinde toplanan atıkların dış ortamda da ayrı toplanabileceği atık kumbaraları kampüs içine yerleştirilmiştir. SAY uygulamasının etkinliğini ölçmek için bina içlerinde toplanan atık miktarları SAY öncesinde ve sonrasında düzenli olarak ölçülmüsstür. Kampüsteki SAY uygulaması ile kâğıt, cam, plastik/metal ve organik atık olmak üzere atığın kategorilerine göre 
toplanması hedeflenmiştir. SAY uygulaması öncesinde ayrıştırılmadan toplanan atıklar ve SAY uygulaması sonrasında ayrıştırılmış atıklar Mayıs 2019 - Kasım 2019 tarihleri arasında günlük olarak tartılmıştır. Atığın miktarının belirlenmesinde $<50 \mathrm{~kg}$ olan atıklar için hassasiyeti 10 gr olan İşgör markalı dijital elektronik el terazisi; $>50 \mathrm{~kg}$ olan atıklar (yemekhane atıkları gibi) için hassasiyeti her 100kg'da 1 gr olan Akpınar markalı EPB model paslanmaz elektronik terazi kullanılmıştır. Kampüste atıkların çıkabileceği noktalar dikkate alınarak i) bina içlerine ayrı atık toplama üniteleri (kâğıt, plastik/metal, cam ve geri dönüştürülemeyen atık olmak üzere; toplam $80 \mathrm{~L}$ kapasiteli, $30 \mathrm{~cm}$ en x $144 \mathrm{~cm}$ boy x $60 \mathrm{~cm}$ yükseklik ölçülerinde), ii) kampüs bahçesine Beykoz Belediyesi desteği ile Atık Getirme Merkezi (300 cm en x $230 \mathrm{~cm}$ boy x $400 \mathrm{~cm}$ yükseklik ölçülerinde) yerleştirilmiştir.

\subsection{Farkındalık Belirleme Çalışması}

Kampüste yer alan öğrencilerin SAY kapsamında yapılan uygulamalarla ilgili farkındalığını ölçmek amacıyla sosyal bilimlerde yaygın olarak kullanılan araştırma yöntemlerinden biri olan anket yöntemi uygulanmıştır. Anketler Marmara Üniversitesi Anadoluhisarı Kampüsünde 2019 bahar yarıyılı vize döneminde (15.05.2019-19.05.2019) gerçekleştirilmiştir. Anket formlarında katılımcılara "SAY hakkında bilgileri olup olmadı̆̆l; Kampüste SAY uygulanıp uygulanmadı̆̆ konusunda ne düşündükleri; Kampüste SAY ile ilgili yeterince bilgilendirme bulunup bulunmadiğl; Kampüste SAY ile ilgili yeterli alt yapının olup olmadığı; Kampüste başlatılan SAY uygulamasının katılımcıların kendilerinde ve çevrelerinde olumlu etki yaratıp yaratmadı̆̆g; Kampüste fakülte yönetiminin, çalışan idari personelin

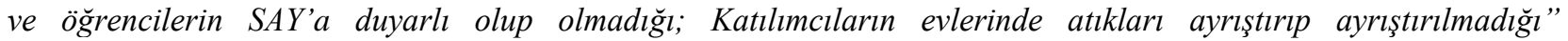
sorulmuştur. Soruların cevaplandırılmasında "evet", "hayır" ve "kısmen" cevaplarından birinin tercih edilmesi beklenmiştir. Anketler, "gözlem altında cevap verme" metodu ile katılımcılara uygulanmıştır. Bu metot kapsamında anket soruları katılımcılara dağıtılmış ve ne şekilde uygulanacağı katılımcılara açıklanmıştır. Çalışma, çalışma evrenini gruplara ayıran küme örneklemi (Çömlekçi, 2001) ve örneklem büyüklüğüne göre rastgele ayrılabilen gelişi güzel örneklem (Arlı ve Nazik, 2001) şeklinde gerçekleştirilmiştir. Kampüsteki derslikleri, yemekhaneyi ve birimlere bağlı binaları kullanan aktif öğrenci sayısının, bir diğer ifadeyle atık üretme potansiyeline sahip öğrenci sayısının toplamda 1600 civarında olduğu belirlenmiştir (Tablo 1). Bu değeri dikkate alarak, \%5 hata payı ve \%95 güven aralığında anket uygulanması gereken öğrenci sayısı 310 olarak tespit edilmiş (url-1). Mevcut çalışmada her üç fakülteden 100'er öğrenci seçilerek, toplam 300 öğrenciye anket uygulanmıştır. Öğrencilere uygulanan anket sonucu analiz edilirken frekans (f) ve yüzde (\%) değerleri üzerinden değerlendirilmiştir. Mevcut çalışmanın asıl odak noktasını kampüs içinde SAY'ın uygulanması sonucu ayrıştırılabilen atıklar ve bunun yarattığı farkın rakamsal ifadesi oluşturduğu için, anket verilerinin değerlendirilmesinde detaylı bir istatistiksel analiz kullanılmamıştır.

\subsection{Kampüsteki Uygulamanın Akışı}

Kampüsteki SAY uygulaması kapsamında gerçekleştirilen çalışma üç aşamada tamamlanmıştır (Şekil 1). İlk aşamada durum tespiti yapılarak atık oluşma noktaları ve miktarı belirlenmiştir. Bir sonraki aşamada SAY sistemi kurulmuştur. Bu kapsamda atığın ayrık toplanacağı noktalar belirlenmiş, bina içine ve dışına atık getirme merkezi yerleştirilmiş ve ayrık toplanan atıklar tartılmıştır. Son aşamada ise farkındalık ölçme çalışması için öğrencilere anket uygulanmıştır. 


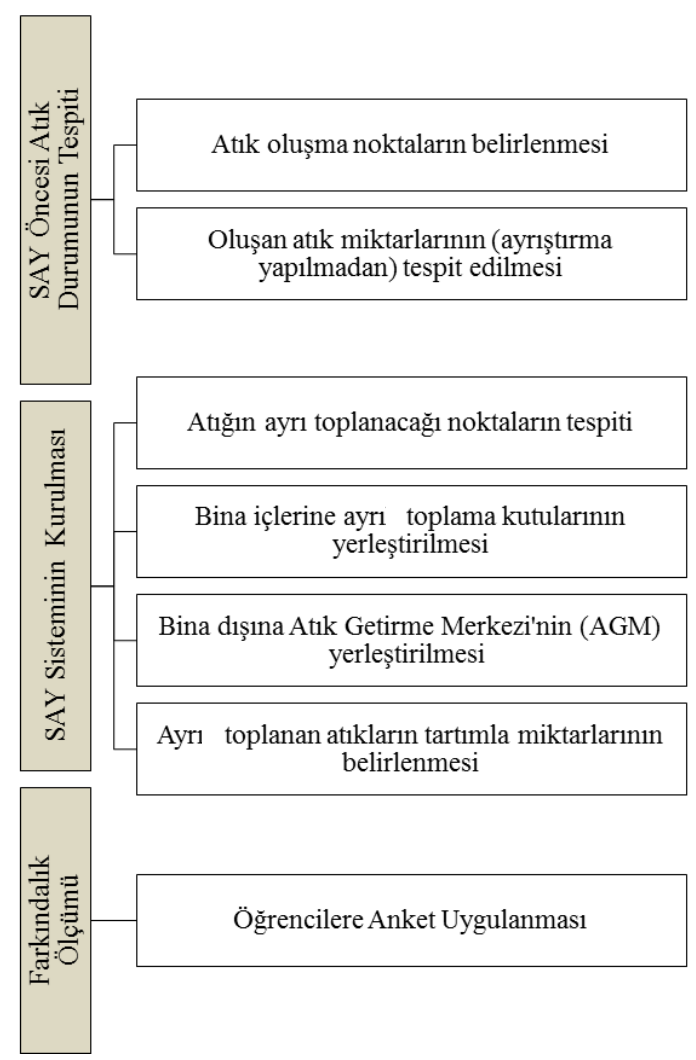

Şekil 1. Çalışma kapsamında gerçekleştirilen adımların şematik gösterimi

\section{BULGULAR VE DEĞERLENDİRME:}

\subsection{SAY Uygulaması Öncesinde Atık Durumunun Tespiti}

Marmara Üniversitesi Anadoluhisarı Kampüsü'nde SAY uygulanmadan önce oluşan atıkların hangi kaynaklardan, ne miktarda geldiği araştırılmışır. SAY öncesinde kampüste oluşan atık türleri ve bu atıkların ne yapıldığı Tablo 2'de özetlenmektedir.

Tablo 2. Kampüs İçinde Oluşan Atık Türleri ve SAY Uygulaması Öncesinde Ne Şekilde Uzaklaştırıldıkları

Atık Türü Açıklamala

\begin{tabular}{|c|c|}
\hline Ambalaj Atıkları & $\begin{array}{l}\text { Binalardan ve yemekhaneden oluklu mukavva (karton), plastik, kâğıt, cam, metal ve kompozit ambalaj } \\
\text { atıkları çıkmaktadır. SAY öncesinde Beykoz Belediyesi aracılığı ile yerleştirilmiş olan, kâğıt, metal ve } \\
\text { plastiğin birlikte toplandığı ambalaj atığı toplama üniteleri bulunmaktadır. Ancak uygulamada bu atıkların } \\
\text { evsel atıklarla birlikte ayrı toplanmadan uzaklaştırıldığı belirlenmiştir. }\end{array}$ \\
\hline Organik Atıklar & $\begin{array}{l}\text { Yemekhaneden, çay ocakları ve ofislerden organik atıklar çıkmaktadır. SAY öncesinde bu atıkların evsel } \\
\text { atıklarla birlikte, ayrı toplanmadan uzaklaştırıldığı belirlenmiştir. }\end{array}$ \\
\hline Atık & $\begin{array}{l}\text { Kampüste yer alan yemekhanede yemek yapılmadığı için bu noktadan atık yağ çıkmamaktadır. Kampüste } \\
\text { oluşabilecek atık yağlar soğutma ve 1sınma sistemlerinin çalışması sonucu ortaya çıkan yağlardır. SAY } \\
\text { öncesinde bu atıkların evsel atıklarla birlikte, ayrı toplanmadan uzaklaştırıldığ belirlenmiştir. }\end{array}$ \\
\hline Elekt & $\begin{array}{l}\text { Kampüs içerisinde kullanılan bilgisayar, yazıcı gibi elektronik malzemeler zamanla elektronik atığa } \\
\text { dönüşmektedir. Toplanan elektronik atıklar binalardaki teknik hizmet odalarında toplanmakta, idare } \\
\text { tarafından sınıflandırılarak depolanmakta ve lisanslı firmalar aracılığıyla elektronik atık tesislerine } \\
\text { gönderilmektedir. }\end{array}$ \\
\hline Tel & $\begin{array}{l}\text { Tehlikeli atık olarak fotokopi makinelerinden çıkan kartuş ve tonerler, aydınlatma sistemlerinde kullanılan } \\
\text { flüoresan lambalar ve atık piller çıkmaktadır. SAY öncesinde tehlikeli atıkların sürekli oluşmadığı, } \\
\text { oluştuğunda evsel nitelikli çöp kutularına atıldığı belirlenmiştir. }\end{array}$ \\
\hline
\end{tabular}


Çalışma öncesinde kampüste oluşan ambalaj atıklarının ayrı toplanması ile ilgili Beykoz Belediyesi'ne ait olan kâğıt, metal ve plastiğin birlikte toplandığı ambalaj atığı toplama üniteleri yer aldığı belirlenmiştir. Ancak uygulamada oluşan atıkların ayrı toplanmasına özen gösterilmediği; ayrı toplanacak olsa bile temizlik personeli tarafından diğer evsel nitelikli katı atıklar ile birleştirilerek uzaklaştırıldığı tespit edilmiş̧ir. Bu durumun temel sebebinin atık üretimini gerçekleştirenlerin (öğrenci, akademik ve idari personel) ayrıştırma konusunda yeterli düzeyde bilgi sahibi olmayışı olarak gözlenmiştir. Bununla birlikte, SAY öncesinde kullanılan kutularının geri dönüştürülebilir atıkların ayrı toplanmasına olanak vermediği tespit edilmiştir.

Bina içlerinde tuvaletler, fotokopi odaları, sınıflar ve ofisler temel atık üretim kaynağını oluşturmaktadır. 07.11.201822.11.2018 tarihlerinde oluşan atıklar 15 gün boyunca vize ve final dönemlerinde her gün ölçülmüştür. Bu dönemde izlenen Siyasal Bilgiler Fakültesi, Spor Bilimleri Fakültesi ve Sosyal Bilimler MYO'da aktif öğrenci sayısı ve ilgili personel sayısı dikkate alınarak belirlenen günlük kişi başına atık miktarı Tablo 3 'te sunulmaktadır.

Tablo 3. Kampüste SAY Uygulaması Öncesinde (07-22.11.2018) Tespit Edilen Atık Kaynakları ve Oluşan Atık Miktarları

\begin{tabular}{|c|c|c|c|c|}
\hline Birimler & Atığın Kaynaklandığı Noktalar & $\begin{array}{l}\text { Aktif } \\
\text { Öğrenci } \\
\text { Sayısı }\end{array}$ & $\begin{array}{c}\text { Personel } \\
\text { Sayısı }\end{array}$ & $\begin{array}{l}\text { SAY Öncesinde Fakülte Temelli } \\
\text { Tespit Edilen Kişi Başı Atık } \\
\text { Miktarları (gr/kişi.gün) }\end{array}$ \\
\hline Siyasal Bilgiler Fakültesi & $\begin{array}{l}\text { Tuvaletler, Fotokopi Odaları, Sinıflar ve } \\
\text { Ofisler }\end{array}$ & 500 & 30 & 53,80 \\
\hline Spor Bilimleri Fakültesi & $\begin{array}{l}\text { Havuz, Kütüphane, Tuvaletler, Çay } \\
\text { Ocakları, Fotokopi Odası, Ofisler ve } \\
\text { Sinıflar }\end{array}$ & 550 & 35 & 61,30 \\
\hline Sosyal Bilimler MYO & $\begin{array}{l}\text { Sinıflar, Ofisler, Çay Ocakları, Tuvaletler, } \\
\text { Fotokopi Odası }\end{array}$ & 550 & 36 & 45,91 \\
\hline Yemekhaneler & $\begin{array}{l}\text { Oluşan ambalaj atıkları (plastik su } \\
\text { bardağı, ekmek poşeti gibi) ve artan } \\
\text { yemek artıkları }\end{array}$ & 456 & 44 & 139,55 \\
\hline
\end{tabular}

Tablo 3'te görüldüğü üzere bina içinde (yemekhane olmadan) kişi başına düşen atık miktarı ortalama değer olarak $53,67 \mathrm{gr} /$ kişi.gün olarak hesaplanmıştır. Yemekhanede oluşan toplam atık (yemek artığı ve ambalaj atığı) miktarı ise 139,55 gr/kişi.gün olarak belirlenmiştir. Bu iki değer dikkate alındığında SAY uygulaması öncesinde kampüste oluşan kişi başı atık miktarı 193,22 gr/kişi.gün olarak tespit edilmiştir. Bu değeri karşılaştırmak üzere yapılan çalışmalar incelendiğinde, Gül (2019) tarafından Namık Kemal Üniversitesi Çorlu Mühendislik Fakültesi’nde gerçekleştirilen bir çalışmada kişi başına düşen atık miktarı $113 \mathrm{~g} /$ kişi-gün olarak belirlendiği görülmektedir. Diğer taraftan, TÜiK verilerine göre ülkemizde kişi başına düşen atık miktarı $1,16 \mathrm{~kg} / \mathrm{kişi.gün} \mathrm{olup,} \mathrm{İstanbul} \mathrm{için} \mathrm{ise} \mathrm{bu}$ değer 1,28 kg/kişi.gün'dür. (TÜİK, 2019) TÜİK değeri (1,16 kg/kişi.gün) esas alınarak, bir öğrencinin yaklaşı 6 saatini okulda geçirdiği varsayıldığında oluşacak atık miktarı $0,29 \mathrm{~kg} /$ kişi.gün olarak hesaplanmaktadır. Çalışmada bulunan değer $(0,19 \mathrm{~kg} / \mathrm{kişi} . g u ̈ n)$ ile beklenen değer arasındaki farkın atık tartımı yapılan dönemde, kampüs içerisindeki önemli atık oluşum noktalarından biri olan kantinlerin kapalı olması olarak açıklanabilmektedir. SAY uygulaması öncesinde kişi başına düşen atık miktarı hesaplanırken, atıkların tamamı "dönüştürülemeyen atık" niteliğinde kabul edilmiştir.

\subsection{Atık Ayrıştırma Çalışmaları}

Kampüste bina içinde oluşan atı̆ğın "kâğıt, plastik-metal, cam ve geri dönüştürülemeyen atık" olmak üzere dört kategoriye ayrıştırılması hedeflenmiş̧tir. Atığın verimli toplanabilmesi için sınıflarda ve ofislerdeki çöp kutuları kaldırılmıştır. Ayrıştırma sistemi kurulurken ayrı toplama ünitelerinden nereye koyulacağı, atıkların çıkış noktasına ve sistemin daha kolay nasıl işleyebileceğine dair tespitler yapılarak atık kutuları sınıflara ve ofislere en yakın yerlere yerleştirilmiştir. Kampüs içinde ayrı toplamanın verimini ölçmek için Siyasal Bilgiler Fakültesi daha detaylı olarak izlenmesi hedeflenmiştir.

Atık üretim kaynakları dikkate alınarak, Siyasal Bilgiler Fakültesi’nin her katına dörtlü ayrı toplama ünitelerinden üçer adet olmak üzere toplam 12 atık kutusu yerleştirilmiştir. Ardından ne kadar atık toplandığının tespit edilmesi için ilk aşama 14.01.2019 - 23.01.2019 ile 12.02.2019 - 28.02.2019 (SAY uygulaması öncesi), ikinci aşama 21.10.2019 01.11.2019 (SAY uygulaması sonrası) tarihlerinde olmak üzere günlük olarak toplanan atıklar tartılarak 
kaydedilmiştir. Siyasal Bilgiler Fakültesinde SAY uygulaması öncesinde kişi başına toplanan atık miktarı 53,80 gr/kişi.gün, SAY uygulaması sonrasında ayrı olarak toplanan toplam atık miktarı 111,69 gr/kişi.gün olarak tespit edilmiştir. Siyasal Bilgiler Fakültesi baz alınarak ortaya koyulan sonuçlara göre iki tartım ile kişi başına düşen atık miktarı \%108 oranında artış göstermiştir. Bu farkın temel sebebi; ofis ve sınıf içerisindeki çöp kutularının kaldırılarak herkesin atıklarını atık ayrıştırma kutularına atmak zorunda kalması olmuştur. SAY öncesinde toplanan tüm atıklar geri dönüştürülemeyecek şekilde toplanıp bertaraf edilirken, SAY uygulaması sonrasında atıklar kategorilerine göre ayrılmış ve geri dönüştürülemeyen atık miktarı önemli ölçüde azaltılmıştır. Siyasal Bilgiler Fakültesi binası içinde SAY öncesi ve sonrası toplanan atık miktarları Tablo 4'te sunulmaktadır. Tablo 4 'te görüldüğü üzere atığın \%25'i cam, \%27'si kağıt ve \%24'ü metal/plastik olarak geri dönüştürülmek amacıyla ayrıştırılmıştır. Toplam atığın SAY öncesinde \%100’ü geri dönüştürülemezken, SAY sonrasında bu değer \%23’e düşürülmüştür.

Tablo 4. Siyasal Bilgiler Fakültesi Binasında SAY Uygulaması Öncesi ve Sonrasında Kişi Başına Düşen Atık Miktarları

\begin{tabular}{|lccccc|}
\hline Toplanan atık, gr/kişi.gün & $\begin{array}{c}\text { Cam } \\
\text { (gr/kişi.gün) }\end{array}$ & $\begin{array}{c}\text { Kağıt } \\
\text { (gr/kişi.gün) }\end{array}$ & $\begin{array}{c}\text { Metal/Plastik } \\
\text { (gr/kişi.gün) }\end{array}$ & $\begin{array}{c}\text { Geri Dönüștürülemeyen } \\
\text { (gr/kişi.gün) }\end{array}$ & $\begin{array}{c}\text { Toplam } \\
\text { (gr/kişi.gün) }\end{array}$ \\
\hline SAY Öncesi & - & - & - & $53,80(\% 100)$ & $53,80(\% 100)$ \\
\hline SAY Sonrası & $28,39(\% 25)$ & $30,43(\% 27)$ & $27,23(\% 24)$ & $25,64(\% 23)$ & $111,69(\% 100)$ \\
\hline
\end{tabular}

Kampüs içinde atığın kaynaklandığı diğer önemli kaynak yemekhane olup, yemekhaneden çıkan atıklar kompostlaştırılabilen organik atık, komposta uygun olmayan organik atık ve metal/plastik atık olarak ayrılmaktadır. Çalışmada komposta uygun olan (çok yağlı olmayan sebze atıkları gibi) yemek artıkları kompostlaştırılmış, metal/plastik atıklar (plastik bardak gibi) ise ayrı toplanmıştır. SAY'ın uygulanması ardından yemekhane atıklarının \%22'si kompostlaştırılmış ve \%42'si metal/plastik ayrı toplanmış, \%36's1 ise geri dönüştürülemeyen atık olarak ayrılmıştır. Toplam yemekhane atığının SAY öncesinde \%100'ü geri dönüştürülemezken, SAY sonrasında bu değer \%36'ya indirilmiştir (Tablo 5).

Tablo 5. Yemekhanede SAY Uygulaması Öncesi ve Sonrasında Kişi Başına Düşen Atık Miktarları

\begin{tabular}{|lcccc|}
\hline $\begin{array}{l}\text { Toplanan Atık } \\
\text { (gr/kişi.gün) }\end{array}$ & $\begin{array}{c}\text { Kompostlaştrrlabilen } \\
\text { Organik Atık } \\
\text { (gr/kişi.gün) }\end{array}$ & $\begin{array}{c}\text { Metal/Plastik } \\
\text { (gr/kişi.gün) }\end{array}$ & $\begin{array}{c}\text { Geri Dönüştürülemeyen } \\
\text { (gr/kişi.gün) }\end{array}$ & $\begin{array}{c}\text { Toplam } \\
\text { (gr/kişi.gün) }\end{array}$ \\
\hline SAY Öncesi & - & - & $139,55(\% 100)$ & $139,55(\% 100)$ \\
\hline SAY Sonrası & $40,23(\% 22)$ & $77,12(\% 42)$ & $66,5(\% 36)$ & $183,85(\% 100)$ \\
\hline
\end{tabular}

Kampüste bir kişi tarafından günlük olarak atılan atığın ne oranda ayrıştırılabildiğini belirlemek üzere Siyasal Bilgiler Fakültesinde tespit edilen değerler tüm kampüs geneli için kabul edilmiştir. Bu kabul yapılırken Tablo 3 'te yer aldığı gibi kişi başı atık miktarının belirlenmesinde her fakülte dikkate alınarak ortalama değerin bulunduğu 53,67 gr/kişi.gün ile yalnızca Siyasal Bilgiler Fakültesi için bulunan 53,80 gr/kişi.gün değerinin yakınlığı göz önünde bulundurulmuştur. Buna bağlı olarak ayrık atık toplama veriminin tespitinde de Siyasal Bilgiler Fakültesi üzerinden kampüs geneli için değerlendirme yapılması anlamlı görülmüştür. Bu kabul üzerinden kampüs geneli için belirlenen kişi başı günlük atık değerleri Tablo 6'da sunulmuştur.

Tablo 6. Kampüste SAY Uygulaması Öncesi ve Sonrasında Kişi Başına Düşen Toplam Atık Miktarları (Siyasal Bilgiler Fakültesi ve Yemekhane Üzerinden Değerlendirilmiştir)

\begin{tabular}{|c|c|c|c|c|c|c|}
\hline $\begin{array}{c}\text { Toplanan Atık } \\
\text { (gr/kişi.gün) }\end{array}$ & $\begin{array}{c}\text { Cam } \\
\text { (gr/kişi.gün) }\end{array}$ & $\begin{array}{c}\text { Kağıt } \\
\text { (gr/kişi.gün) }\end{array}$ & $\begin{array}{c}\text { Metal/ } \\
\text { Plastik } \\
\text { (gr/kişi.gün) }\end{array}$ & $\begin{array}{c}\text { Kompostlaştırılabilen } \\
\text { Organik Atık } \\
\text { (gr/kişi.gün) }\end{array}$ & $\begin{array}{c}\text { Geri } \\
\text { Dönüsştürüleme } \\
\text { yen (gr/kişi.gün) }\end{array}$ & $\begin{array}{c}\text { Toplam } \\
\text { (gr/kişi.gün) }\end{array}$ \\
\hline SAY Öncesi & - & - & - & - & $\begin{array}{l}193,35 \\
(\% 100)\end{array}$ & $\begin{array}{l}193,35 \\
(\% 100)\end{array}$ \\
\hline SAY SonrasI & $\begin{array}{l}28,39 \\
(\% 9)\end{array}$ & $\begin{array}{l}30,43 \\
(\% 11)\end{array}$ & $\begin{array}{l}104,35 \\
(\% 35)\end{array}$ & $\begin{array}{l}40,23 \\
(\% 14)\end{array}$ & $\begin{array}{l}92,14 \\
(\% 31)\end{array}$ & $\begin{array}{l}295,54 \\
(\% 100)\end{array}$ \\
\hline
\end{tabular}


Tablo 6'da görüldüğü üzere, Siyasal Bilgiler Fakültesi üzerinden değerlendirme yapıldığında, SAY uygulaması öncesinde toplanan atık miktarı 193,35 gr/kişi.gün olup, bu atık tamamen geri dönüştürülemez niteliktedir. SAY uygulaması sonrasında özellikle sınıf ve ofislerdeki çöp kutularının kaldırılmasıyla oluşan atık miktarı daha doğru olarak tespit edilerek oluşan atık miktarının 295,54 gr/kişi.gün olduğu belirlenmiştir. SAY uygulaması ile bu atık \%9 oranında cam, \%11 oranında kâğıt, \%35 oranında metal/plastik ve \%14 oranında fraksiyonlarına ayrılabilmiştir. Diğer taraftan, atığı \%69 oranında geri dönüştürülebilir kısmı ayrılarak, geri dönüştürülemeyen kısmı \%31 oranına indirilmiştir.

Literatürdeki çalışmalar incelendiğinde, Adeniran ve arkadaşları (2017) tarafindan Nijerya'daki Lagos Üniversitesi'nde katı atık yönetimi ve karakterizasyonu üzerine yapılan benzer bir çalışmada toplam atı̆ğ \% \% 75 'nin geri dönüştürülebildiği belirlenmiştir. Unilag Akoka kampüsünde günlük katı atık üretimi ortalama 32,2 ton olarak belirlenmiş, atığın $\% 24$ 'ü polietilen torbalar, \%15'i kağıt, \%15'i organik madde \%9'u plastik, \%8'i inert malzeme, $\% 7$ 'si sıhhi atık, \%7'si tekstil, \%4'ü deri, \%3'ü metal, ve \%2'si cam olarak karakterize edilmiştir (Adeniran ve ark., 2017). Malezya Teknoloji Üniversitesi'nde gerçekleştirilen bir diğer çalışmada "Yeşil Ofis" çalışması ile kampüslerdeki atığın en aza indirilmesi ve geri dönüștürülmesi hedeflenmiștir (Zen ve ark., 2016). Bu kapsamda çalışma öncesi atık karakterizasyonunda toplam atı̆̆ın \%46'sı kompostlaştırılabilir veya yemek atığı olarak \%41'i kuru atık veya geri dönüştürülebilir atık (\%40'1 kağıt, \%32'si plastik ambalaj, \%17'si plastik şişe ve \%11'i plastik kutu) olarak belirlenmiştir. Yeşil Ofis çalışması ile kuru atıkların minimize edilmesine kâğıt geri dönüşümüne gidilmiştir. Yıllara bağlı olarak oluşan kâğıt atıktaki azaltım sırasıyla \%30 (2011), \%42 (2012) ve \%58 (2013) oranında gözlenmiştir (Zen ve ark., 2016).

\subsection{Farkındalık Belirleme Çalışmaları}

Öğrencilerin SAY konusunda ne kadar bilgi sahibi olduklarını, kampüste yeni uygulanmakta olan SAY sisteminin ne ölçüde farkında olduklarını ve kampüs içinde SAY'a olan yaklaşımlarını tespit etmeyi hedefleyen bir anket uygulanmıştır. SAY'nin pek çok boyutuna değinen ve fakülteler arasında karşılaştırmalı bir analiz sunma hedefiyle hazırlanan anket sorularının, çalışmanın kapsamını aşmaması adına yalnızca belirli bir kısmı bu çalışma çerçevesinde paylaşılmıştır. Anketlerde yer alan sorular ve her fakülte özelinde öğrenciler tarafindan verilen cevaplar Tablo 7'de sunulmaktadir.

Tablo 7'de görüldüğü üzere ankette yöneltilen sorulardan ilki öğrencinin SAY hakkında bilgisi olup olmadığını ölçmeye yönelik olmuştur. Bu soruya verilen cevap ağırlıklı olarak "kısmen" cevabı (\%50) olmuştur. Öğrencilerin yalnızca \%12'si SAY hakkında bilgisi olduğunu belirtmiş, \%38'lik kısmı ise "hayır" cevabını vermiştir. Verilen "hayır" cevabının, Fakülteler arasındaki dağılımına bakıldığında, Spor Bilimleri Fakültesi öğrencilerinin neredeyse yarısının SAY konusunda hiç bilgisi olmadığı (\%49), diğer iki Fakülte öğrencilerinin ise yaklaşık üçte birinin bu konuda hiç bilgisi olmadığı belirlenmiştir (Siyasal Bilgiler Fakültesi öğrencilerin \%36's1, Sosyal Bilimler MYO öğrencilerinin \%30'u hayır cevabını vermiştir). Literatürde yer alan benzer bir çalışmada İstanbul'da 6 üniversite ve 1 meslek Yüksek Okulunda yer alan farklı fakülte ve bölümlerdeki 447 öğrenciye anket uygulanmıştır. Ankette yöneltilen katı atık toplama uygulamalarından ne derece haberdarsınız sorusuna verilen cevaplardan en çok Fen Bilimleri öğrencilerinin, en az Sosyal Bilimler öğrencilerinin haberdar oldukları belirlenmiştir (Zülfikar, 2013).

Ankette yer alan diğer sorular içinde kampüste SAY uygulanmasının ne oranda fark edildiği ve bu konudaki bilgilendirme ve altyapı ile ilgili ne düşünüldüğü sorulmuştur. Kampüste SAY'ın uygulanıp uygulanmadığı sorusuna öğrencilerin yalnızca \%22'si uygulandığı cevabını vermiştir. Öğrencilerin \%31'i 'hayır', \%47'si ise 'kısmen' yanıtını vermiştir. SAY sisteminin kampüste kurulmasından (Ocak 2019) ve ayrı atık kutularının bina içi ve dışına yerleştirilmesinden (ve aynı zamanda ofis ve sınıflarda yer alan atık kutularının tamamen kaldırılmasından) dört ay sonra gerçekleştirilen ankette (Mayıs 2019) bu soruya verilen \%22 oranda "uygulanmaktadır" cevabı beklenin altında olmuştur. Anketteki diğer bir soru olan "Kampüste SAY ile ilgili yeterli alt yapı mevcut mudur" sorusuna yalnızca \%16 oranında verilen "evet" cevabı benzer şekilde beklenenin altındadır. Kampüsteki öğrencilerin çoğunluğu (\%53) SAY için altyapının kısmen yeterli olduğunu belirtmiştir. Fakülteler arasındaki karşılaştırma yapıldığında en az farkındalığın \%14 oranla Siyasal Bilgiler Fakültesinde olduğu gözlenmiştir.

Bir önceki bölümde sunulan kampüsteki atıkların ayrı toplanma yüzdesi dikkate alındığında başlangıçta tamamı ayrıştırılmadan atılan atıkların, SAY uygulaması ardından \%69'u ayrıştırılmış, geri dönüştürülemeyen kısım \%31'e düşmüştür. $\mathrm{Bu}$ uygulamayı gerçekleştirenlerin kampüste önemli farkla çoğunlukta olan öğrenciler olduğu düşünüldüğünde, öğrencilerin atıkları ayrı atma davranışlarının SAY sisteminin bilincinde olmadan yaptıkları 
belirlenmektedir. Bu durum, öğrencilerin davranışlarını ne amaca hizmet ettiğini bilmeden gerçekleştirmeleri olarak açılanabilmektedir. Elde edilen sonuç, kampüste SAY sisteminin uygulanmasına dair yapılan bilgilendirmelerin yeterli gelmemiş olması ile ilişkilendirilmektedir. Bu sonucu destekleyecek şekilde ankette sorulan "kampüste SAY ile ilgili sizce yeterince bilgilendirme bulunmakta mıdır" sorusuna verilen cevapların yalnızca \%12'si "evet" olmuştur. Kalanın \%57'si "hayır", \%31'i "kısmen" demiştir. Fakülteler arasındaki dağılımda, Siyasal Bilgileri Fakültesi öğrencilerinin \%73’ü bilgilendirmenin yeterli olmadığını düşünürken, Spor Bilimleri Fakültesi öğrencilerinin \%57'si, Sosyal Bilimler MYO öğrencilerinin ise \%42'si bu şekilde düşünmektedir. Bu veriler bizlere SAY ile ilgili daha fazla bilgilendirme faaliyetlerinde bulunulması gerekliliğini göstermektedir. Bilgilendirme faaliyetlerinin başında eğitimin geldiği düşünülmektedir. Literatürde eğitimin çevre duyarlılı̆̆ üzerine olan etkisini inceleyen çalışmalarda, eğitimin önemli ölçüde olumlu etkisi olduğu tespit edilmiştir (Eryılmaz ve Kıran, 2017; Şenyurt ve ark., 2011; Aksoy ve Karatekin, 2011). Eğitimin dışında görünürlük faaliyetlerinin farkındalık üzerinde önemli etkileri olabilmektedir. Tayland'da yer alan bir yüksek eğitim kurumunda atık azaltım ve geri dönüşüm uygulamaları gerçekleștirilmiş ve kampüsteki öğrencilerin davranışları üzerinde etkisi incelenmiștir. Gelinen sonuçta gönüllü araçların tek başına etkili sonuçlar vermediği ve kampanyalar gibi görünürlük faaliyetlerinin geri dönüşüm oranını \%10 arttırdığı belirlenmiştir (Tangwanichagapong ve ark., 2017).

Ankette SAY için fakülte yönetiminin, idari personelin ve öğrencilerin bu konudaki duyarlılığına ilişkin sorular yöneltilmiştir. Fakülte yönetiminin bu konuda duyarlılığı ile ilgili öğrencilerin çoğu (\%54) "kısmen" diyerek kararsız olduğunu belirtmiştir, "evet" cevabı \%24 oranında verilmiştir. Fakülteler arasında yönetimin en az duyarlı olduğu düşünülen \%11 "evet" cevabı ile Siyasal Bilgiler Fakültesi olmuştur. İdari personelin duyarlılı̆̆ konusunda yakın cevaplar elde edilmiştir. Öğrencilerin \%27'si idari personelin duyarlı olduğunu düşünürken, çoğunluğu (\%54) kararsız olduğunu belirtmiştir. Öğrencilere kampüsteki diğer öğrencilerin SAY konusundaki duyarlılıkları sorulduğunda \%19'nun duyarl1, \%32'sinin duyarsız olduğu belirtilmiştir. Fakülte yönetimi, idari personel ve öğrencilerin duyarlılıklarına ilişkin sorulan üç soruda da en az duyarlı olduğu düşünülen Fakülte, Siyasal Bilgiler Fakültesi olmuştur. Çevreyle ilgili olumlu yaklaşımların Fakülteler arasındaki ayrımını araştıran bir başka çalışmada Tokat Gaziosmanpaşa Üniversitesi bünyesindeki 13 Fakülte incelenmiştir. Çevreye ilişkin olumlu yaklaşımlar en fazla Beden Eğitimi ve Spor Yüksekokulu öğrencilerinde, en az Teknik Bilimler Meslek Yüksek Okulu öğrencilerinde gözlenmiştir (Acungil, 2020). Ankara Üniversitesi lisans öğrencilerine uygulanan başka bir çalışmada çevre bilgisi ve duyarlılığını belirlenmesi hedeflenmiş ve sağlık bilimleri ile ilgili programlarda yer alan öğrencilerin büyük farklarla daha duyarlı oldukları tespit edilmiştir (Talay ve ark., 2004). Gerek bizim çalışmamızda gerek benzer diğer çalışmalarda farklı Fakülte öğrencilerinin aldıkları eğitime göre çevrenin korunması konusunda farklı hassasiyetler gösterebildiği görülmektedir.

Ankette yer alan diğer soru öğrencilerin atıklarını evlerinde ayrıştırıp ayrıştırmadıkları üzerine olmuştur. Öğrencilerin \%33'ü atıklarını evde ayrıştırdıklarını, \%39'u ise ayrıştırmadığını belirtmiştir. Evinde en çok atık ayrıştıran öğrenciler Sosyal Bilimler MYO'da iken (bu fakülte öğrencilerinin \%40’1 "evet" demiştir), en az atık ayrıştıran öğrenciler Siyasal Bilgiler Fakültesindedir (bu fakülte öğrencilerinin \%45'i "hayır" demiştir). Öğrencilerin kampüste ve evde atık ayrıştırma tutumlarını karşılaştırmak için anketteki "Kampüs öğrencisi sizce SAY'a duyarlı mıdır?" sorusu ile "Atıklarınızı evinizde ayrıştırır mısınız?" sorusunun cevapları karşılaştırılmıştır. Alınan cevaplar doğrultusunda öğrencilerin kampüstense kendi evlerinde bu konuya (nispeten) daha duyarlı oldukları belirlenmiştir.

Anketteki "Kampüste başlatılan SAY uygulaması bende ve çevremde olumlu etki yarattı" ifadesine yönelik öğrencilerin \%37'si "evet", \%16'sı "hayır" cevabını vermiştir, en çok tercih edilen "kısmen" seçeneği olmuştur (\%47). Bu soruya verilen cevaplara yönelik Fakülteler arasında belirgin bir ayrım gözlenmemiştir. Öğrencilerin farkındalığının artmasıyla söz konusu olumlu etkinin de artacağı düşünülmektedir.

Tablo 7. Katılımcılara Yönetilen İfadeler ve Birimlerine Göre Verilen Cevaplar (Frekans ve Yüzde)

\begin{tabular}{lcccccccc}
\hline İfade & \multicolumn{2}{c}{ Evet } & \multicolumn{2}{c}{ Hayır } & \multicolumn{2}{c}{ Kismen } & \multicolumn{2}{c}{ Toplam } \\
\hline & $\boldsymbol{f}$ & $\boldsymbol{\%}$ & $\boldsymbol{f}$ & $\mathbf{\%}$ & $\boldsymbol{f}$ & $\mathbf{\%}$ & $\boldsymbol{f}$ & $\mathbf{\%}$ \\
\hline "SAY hakkında bilgim var" & & & & & & & & \\
\hline Siyasal Bilgiler Fakültesi & 11 & 11 & 36 & 36 & 53 & 53 & 100 & 100 \\
\hline Spor Bilimleri Fakültesi & 9 & 9 & 49 & 49 & 42 & 42 & 100 & 100 \\
\hline Sosyal Bilimler MYO & 16 & 16 & 30 & 30 & 54 & 54 & 100 & 100 \\
\hline & & & & & & & & \\
\hline Toplam & 36 & 12 & 115 & 38 & 149 & 50 & 300 & 100 \\
\hline
\end{tabular}

"Sizce kampüste SAY uygulanmakta mıdır?" 


\begin{tabular}{|c|c|c|c|c|c|c|c|c|}
\hline \multirow[t]{2}{*}{ İfade } & \multicolumn{2}{|c|}{ Evet } & \multicolumn{2}{|c|}{ Hayır } & \multicolumn{2}{|c|}{ Kismen } & \multicolumn{2}{|c|}{ Toplam } \\
\hline & $f$ & $\%$ & $f$ & $\%$ & $f$ & $\%$ & $f$ & $\%$ \\
\hline Siyasal Bilgiler Fakültesi & 14 & 14 & 33 & 33 & 53 & 53 & 100 & 100 \\
\hline Spor Bilimleri Fakültesi & 27 & 27 & 25 & 25 & 48 & 48 & 100 & 100 \\
\hline Sosyal Bilimler MYO & 26 & 26 & 34 & 34 & 40 & 40 & 100 & 100 \\
\hline Toplam & 67 & 22 & 92 & 31 & 141 & 47 & 300 & 100 \\
\hline \multicolumn{9}{|c|}{$\begin{array}{l}\text { "Kampüste SAY ile ilgili yeterince } \\
\text { bilgilendirme bulunmaktadır." }\end{array}$} \\
\hline Siyasal Bilgiler Fakültesi & 4 & 4 & 73 & 73 & 23 & 23 & 100 & 100 \\
\hline Spor Bilimleri Fakültesi & 16 & 16 & 57 & 57 & 32 & 32 & 100 & 100 \\
\hline Sosyal Bilimler MYO & 16 & 16 & 42 & 42 & 37 & 37 & 100 & 100 \\
\hline Toplam & 36 & 12 & 172 & 57 & 92 & 31 & 300 & 100 \\
\hline \multicolumn{9}{|c|}{$\begin{array}{l}\text { "Kampüsümüzde SAY ile ilgili yeterli alt yap1 } \\
\text { mevcuttur." }\end{array}$} \\
\hline Siyasal Bilgiler Fakültesi & 10 & 10 & 37 & 37 & 53 & 53 & 100 & 100 \\
\hline Spor Bilimleri Fakültesi & 21 & 21 & 27 & 27 & 52 & 52 & 100 & 100 \\
\hline Sosyal Bilimler MYO & 16 & 16 & 28 & 28 & 56 & 56 & 100 & 100 \\
\hline Toplam & 47 & 16 & 92 & 31 & 161 & 53 & 300 & 100 \\
\hline \multicolumn{9}{|c|}{$\begin{array}{l}\text { "Kampüste başlatılan SAY uygulaması bende } \\
\text { ve çevremde olumlu etki yaratt1." }\end{array}$} \\
\hline Siyasal Bilgiler Fakültesi & 37 & 37 & 18 & 18 & 45 & 45 & 100 & 100 \\
\hline Spor Bilimleri Fakültesi & 34 & 34 & 15 & 15 & 51 & 51 & 100 & 100 \\
\hline Sosyal Bilimler MYO & 39 & 39 & 16 & 16 & 45 & 45 & 100 & 100 \\
\hline Toplam & 110 & 37 & 49 & 16 & 141 & 47 & 300 & 100 \\
\hline
\end{tabular}

"Kampüs ve fakülte yönetimi SAY'a oldukça

duyarlıdır."

\begin{tabular}{lllllllll}
\hline Siyasal Bilgiler Fakültesi & 11 & 11 & 28 & 28 & 61 & 61 & 100 & 100 \\
\hline Spor Bilimleri Fakültesi & 31 & 31 & 17 & 17 & 52 & 52 & 100 & 100 \\
\hline Sosyal Bilimler MYO & 31 & 31 & 20 & 20 & 49 & 49 & 100 & 100 \\
\hline \multicolumn{1}{l}{ Toplam } & & & & & & & & \\
\hline
\end{tabular}

"Kampüs içinde çalışan personeller SAY'a

oldukça duyarlıdır."

\begin{tabular}{lllllllll}
\hline Siyasal Bilgiler Fakültesi & 16 & 16 & 22 & 22 & 62 & 62 & 100 & 100 \\
\hline Spor Bilimleri Fakültesi & 40 & 40 & 11 & 11 & 49 & 49 & 100 & 100 \\
\hline Sosyal Bilimler MYO & 25 & 25 & 23 & 23 & 52 & 52 & 100 & 100 \\
\hline \multicolumn{1}{l}{ Toplam } & & & & & & & & \\
\hline
\end{tabular}

"Kampüs öğrencisi SAY'a oldukça

duyarlıdır."

\begin{tabular}{lllllllll}
\hline Siyasal Bilgiler Fakültesi & 8 & 8 & 37 & 37 & 55 & 55 & 100 & 100
\end{tabular}

Spor Bilimleri Fakültesi

Sosyal Bilimler MYO

\begin{tabular}{lcccccccc} 
Siyasal Bilgiler Fakültesi & 8 & 8 & 37 & 37 & 55 & 55 & 100 & 100 \\
\hline Spor Bilimleri Fakültesi & 28 & 28 & 32 & 32 & 40 & 40 & 100 & 100 \\
\hline Sosyal Bilimler MYO & 22 & 22 & 28 & 28 & 50 & 50 & 100 & 100 \\
\hline & & & & & & & & \\
\hline Toplam & 58 & 19 & 97 & 32 & 145 & 48 & 300 & 100 \\
\hline
\end{tabular}

"Evimde atıklarımı ayrıştırırım."

Siyasal Bilgiler Fakültesi

Spor Bilimleri Fakültesi

Sosyal Bilimler MYO

\begin{tabular}{llllllll}
32 & 32 & 45 & 45 & 23 & 23 & 100 & 100 \\
28 & 28 & 40 & 40 & 32 & 32 & 100 & 100 \\
40 & 40 & 32 & 32 & 28 & 28 & 100 & 100 \\
\hline & & & & & & & \\
100 & 33 & 117 & 39 & 83 & 28 & 300 & 100 \\
\hline
\end{tabular}

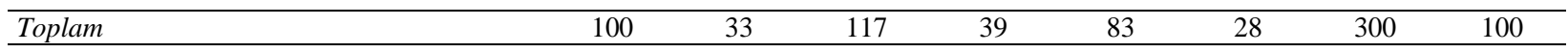




\section{SONUÇ}

Mevcut çalışmada Marmara Üniversitesi Anadoluhisarı Kampüsü’nde SAY uygulaması pilot ölçekte gerçekleştirilmiştir. Çalışma sonucunda elde edilen sonuçlar aşağıda sıralanmaktadır;

- SAY uygulaması öncesinde kampüste toplanan atıkların tamamı geri dönüştürülemeyen atık niteliğinde olup, bu değer (yemekhane dahil) 193,2 gr/kişi.gün olarak tespit edilmiştir.

- SAY uygulamasının gerçekleştirilmesi ile kişi başına düşen atık miktarı; 295,54 gr/kişi.gün olarak hesaplanmıştır.

- SAY uygulaması sonrasında geri dönüştürülemeyen atık miktarı \%69 oranda azaltılarak, \%31 oranına düşürülmüştür.

- SAY uygulaması sonrasında atığın \%9'u cam, \%35'i metal/plastik, \%11'i kâğıt ve \%14'ü kompostlaşabilir organik atık olarak geri kazanılmıştır.

- Farkındalığın tespiti amacıyla kampüsteki öğrencilere uygulanan anketlerde öğrencilerin yalnızca \%12'sinin SAY hakkında bilgi sahibi olduğu, öğrencilerin önemli bir kısmının yeterince bilgi sahibi olmadığı belirlenmiştir.

- Kampüsteki SAY uygulamasının öğrencilerin çoğunun yeteri kadar farkında olmadığı sonucuna ulaşılmıştır. Bu durum SAY uygulaması hakkında kampüsteki mevcut bilgilendirme ve yönlendirme faaliyetlerinin yeterli gelmemesi ile iliş̧kilendirilmiştir.

- Kampüsteki fakülte yönetimi, idari personel ve öğrencilerin SAY konusunda yeterince duyarlı olmadıklarının düşünüldüğg̈ tespit edilmiştir. İncelenen fakülteler içinde en az duyarlılık oranı Siyasal Bilgiler Fakültesinde belirlenmiştir.

Bu çalışma ile üniversite kampüslerinde SAY uygulanabilmesine dair hem nicel hem de nitel ölçümlerle literatüre katk1 sağlanmaya çalışılmışıı. Çalışmada sunulan veriler etkin bir SAY uygulaması ile atıkların büyük bir çoğunluğunun geri kazanılabildiğini göstermiştir. Sosyal boyutuna dair yapılan analizlerle bu konuda daha fazla eğitim faaliyetlerine yer vermek, müfredatlarda çevreye ilişkin dersleri arttırmak ve daha dikkat çekici yönlendirmeler kullanarak SAY'ın daha etkin bir şekilde uygulanabileceği sonucuna varılmıştır.

\section{TEŞEKKÜR}

Bu çalışma, " Sıfır Atık Yönetimi, Marmara Üniversitesi Anadoluhisarı Kampüsü Örneği" isimli ve 6094'no’lu Marmara Üniversitesi-Bilimsel Araştırma Projesi (MÜ-BAP) kapsamında desteklenmiştir. Çalışmada desteği olan Beykoz Belediyesi'ne ve Marmara Üniversitesi Anadoluhisarı Kampüsü İdari Personeline teşekkürlerimizi sunarız.

\section{Etik Standart ile Uyumluluk}

Çıkar Çatışması: Yazarlar herhangi bir çıkar çatışmasının olmadığını beyan eder.

Etik Kurul İzni: Bu çalışma için etik kurul iznine gerek olmadığını beyan ederim.

Finansal Destek: Yok

Teşekkür: Yok.

\section{KAYNAKÇA:}

Acungil, Y. (2020). Üniversite öğrencilerinin çevresel tutum ve davranış düzeylerini belirlemeye yönelik bir çalışma: Tokat Gaziosmanpaşa Üniversitesi örneği. Ankara Üniversitesi SBF Dergisi, 75 (3), 997 - 1032.

Adeniran, A. E., Nubi, A. T., Adelopo, A. O. (2017). Solid Waste Generation and Characterization in the University of Lagos for a Sustainable Waste Management. Waste Management, 67, 3-10.

Akın, B. (2020). Erciyes Üniversitesi'nde Sıfır Atık Yönetiminin Gerçekleştirilmesi, Erciyes Üniversitesi, Fen Bilimleri Enstitüsü, Çevre Mühendisliği Anabilim Dalı, Yüksek Lisans Tezi, Kayseri.

Aksoy, B., Karatekin, K. (2011). Farklı programlardaki lisans öğrencilerinin çevreye yönelik duyuşsal eğilimleri. Türkiye Sosyal Araştırmalar Dergisi, 153, 23-36.

Arlı, M., Nazik, H. (2001). Bilimsel araştırmaya giriş. Ankara: Gazi Kitabevi.

Armijo de Vega, C. A., Benítez, S. O., Barreto, M. E. R. (2008). Solid waste characterization and recycling potential for a university campus. Waste Management, 28, S21-S26. 
Bahçelioğlu, E., Buğdaycı, E. S., Doğan, N. B., Şimşek, N., Kaya, S. Ö., Alp, E. (2020). Integratedsolidwastemanagementstrategy of a largecampus: a comprehensivestudy on METU campus, Turkey. Journal of Cleaner Production, 265, 121715.

Bilgin, R (2020). Niğde Belediyesi binasında sıfır atık uygulamaları, Aksaray Üniversitesi / Fen Bilimleri Enstitüsü / Çevre Mühendisliği Anabilim Dalı, Yüksek Lisans Tezi, Aksaray.

Büyükbektaş, F., Varınca, K. B. (2008). Entegre Atık Yönetimi Kavramı ve AB Uyum Sürecinde Atık Çerçeve Yönetmeliği. Üniversite Öğrencileri III. Çevre Sorunları Sempozyumu (ÇESKO), İstanbul, 15-16.

Büyükkol, M. (2019). Antalya'da faaliyet gösteren beş yıldızlı otel işletmelerinde sıfır atık projesinin uygulanabilirliği, Necmettin Erbakan Üniversitesi, Fen Bilimleri Enstitüsü, Çevre Mühendisliği Anabilim Dalı Yüksek Lisans Tezi, Konya.

Cheremisinoff, N. P., 'Handbook of Solid Waste Management and Waste Minimization Technologies', Elsevier Science, Burlington, USA, 2003.

Çömlekçi, N. (2001). Bilimsel araştırma yöntemi ve istatistiksel anlamlılık sınamaları. Ankara: Bilim Teknik Yayınevi.

ÇŞB, Çevre ve Şehircilik Bakanlığı (2017). 2016-2023 Ulusal Atık Yönetimi Eylem Planı, Çevre ve Şehircilik Bakanlığı, 2017, Ankara.

ÇŞB, Çevre ve Şehircilik Bakanlığı (2019). Sıfır Atık Yönetmeliği, 12.07.2019, RG No: 30829, Çevre ve Şehircilik Bakanlığı, 2019, Ankara.

Demir, K., Şahinkaya, S. (2019). Adana ilinde sıfır atık projesinin uygulanması, Nevşehir Hacı Bektaş Veli Üniversitesi, Fen Bilimleri Enstitüsü, Yüksek Lisans Tezi, Nevşehir

Dönmez, E., Değirmen, N. (2016). Avrupa Birliği (AB) ve Türkiye'deki Atık Yönetimi Uygulamalarının Karşılaştırılması. ISEM 2016, 3rd International Symposium on Environment and Morality, Antalya.

Erdur, E. (2019). Türkiye'de sıfır atık projesi ve projenin kamu kurumlarında uygulanması; Süleymanpaşa belediyesi örneği, Gazi Üniversitesi, Fen Bilimleri Enstitüsü, Çevre Bilimleri Anabilim Dalı, Yüksek Lisans Tezi, Ankara.

Eryılmaz, Ç., Kıran, Ö. (2017). Üniversite öğrencilerinin çevre algısı: Sinop Üniversitesi örneği. Akademik Sosyal Araştırmalar Dergisi, 5(61), 186-199.

Ferronato, N., D'Avino, C., Ragazzi, M., Torretta, V., De Feo, G. (2017). Social surveys about solid waste management within higher education institutes: A comparison. Sustainability, 9(3), 391.

Gray, Alex. (2017). "Germany recycles more than any other country" . Erişim Adresi: https://www.weforum.org/agenda/2017/12/germany-recycles-more-than-any-other-country/, Erişim Tarihi: 08.09.2020.

Gül, B. (2019). Sürdürülebilir Sıfır Atık Yönetimi İçin Eğitim Alanlarında Katı Atık ve Karakterizasyonu, Namık Kemal Üniversitesi, Fen Bilimleri Enstitüsü, Çevre Mühendisliği Anabilim Dalı, Yüksek Lisans Tezi, Tekirdağ.

Karakaya, İ. (2008). İstanbul için Stratejik Kentsel Katı Atık Yönetimi Yaklaşımı, İstanbul Teknik Üniversitesi, Fen Bilimleri Enstitüsü, Çevre Mühendisliği Anabilim Dalı, Doktora Tezi, İstanbul.

Karaman, S. (2019). Kayseri şehir hastanesi örneği sıfır atık projesinin geliştirilmesi, Erciyes Üniversitesi, Fen Bilimleri Enstitüsü, Çevre Mühendisliği Anabilim Dalı, Yüksek Lisans Tezi, Kayseri.

Köse, H. Ö., Ayaz, S., Köroğlu, B. (2007). Türkiye'de Atık Yönetimi Ulusal Düzenlemeler ve Uygulama Sonuçlarının Değerlendirilmesi. Performans Denetimi Raporu, TC Sayıştay Başkanlığı. Ankara.

Malakahmad, D., Amirhossein, D., Nasir, C. M., Za'im Zaki, M., Kutty, S. R. M., Isa, M. H. (2010). Solid Waste Characterization and Recycling Potential for University Technology Petronas Academic Buildings. American Journal of Environmental Sciences, 6(5), 422-427.

Martinez, N. M. J., Borrios, R. G. (2020). Zero Waste University in Mexico: A Model For Grassroots İnnovations in Sustainability. Regional Centre For Multidisciplinary Research, National Autonomous University of Mexico, Mexico.

Mbuligwe, S. E. (2002). Institutional solid waste management practices in developing countries: a case study of three academic institutions in Tanzania. Resources. Conservation and Recycling, 35(3), 131-146.

Okutan, P. (2017). Green Campus Application: Boğaziçi University. Boğaziçi Üniversitesi, Fen Bilimleri Enstitüsü, İnşaat Mühendisliği Anabilim Dalı, Yüksek Lisans Tezi, İstanbul.

Ömürbek, V., Çiğdem, E. R. K., Herek, S. (2019). Üniversitelerde Atık Yönetimi Uygulamaları. Süleyman Demirel Üniversitesi Sosyal Bilimler Enstitüsü Dergisi, (35), 124-161. 
Palabıyık, H. (2001). Belediyelerde Kentsel Katı Atık Yönetimi: İzmir Büyükşehir Belediyesi Örneği, Dokuz Eylül Üniversitesi Sosyal Bilimler Enstitüsü, Doktora Tezi, İzmir.

Smyth, D. P., Fredeen, A. L., Booth, A. L. (2010). Reducing Solid Waste in Higher Education: The First Step Towards 'Greening' A University Campus. Resources. Conservation and Recycling, 54(11), 1007-1016.

Şenyurt, A., Temel, A. B. ve Özkahraman, Ş. (2011). Üniversite öğrencilerinin çevresel konulara duyarlılıklarının incelenmesi. Süleyman Demirel Üniversitesi Sağllk Bilimleri Enstitüsü Dergisi, 2(1), 8-15.

Talay, İ., Gündüz, S. ve Akpınar, N. (2004). On the Status of Environmental Education and Awareness of Undergraduate Students at Ankara University, Turkey. International Journal of Environment and Pollution, 21 (3), 293-308.

Tangwanichagapong, S., Nitivattananon, V., Mohanty, B., Visvanathan, C. (2017). Greening of a Campus Through Waste Management Initiatives: Experience From a Higher Education Institution in Thailand. Int. J. Sustain. High Educ. 18 (2), 203-217. https://doi.org/10.1108/IJSHE-10-2015-0175.

TÜİK, 2019. Belediye Atık İstatistikleri, 2018, Türkiye İstatistik Kurumu Haber Bülteni, Ankara.

Ulaşı, K. (2018). Geri kazanılabilir atıkların yönetimi ve sıfır atık projesi uygulamaları: Kadıköy Belediyesi, Hasan Kalyoncu Üniversitesi, Fen Bilimleri Enstitüsü, Çevre Bilimleri ve Enerji Yönetimi Anabilim Dalı, Yüksek Lisans Tezi, Gaziantep.

Url-1. Sample Size Calculation http://www.raosoft.com/samplesize.html, Erişim Tarihi: 15.09.2019

Yıldız, Ş., Saltabaş, F., Balahorli, V., Sezer, K.,Yağmur, K. (2009). Organik Atıklardan Biyogaz Üretimi (Biyometanizasyon) Projesi-İstanbul Örneği. TÜRKAY Türkiye'de Katı Atık Yönetimi Sempozyumu, 15-17.

Yılmaz, A., Bozkurt, Y. (2010). Türkiye'de Kentsel Katı Atık Yönetimi Uygulamaları ve Kütahya Katı Atık Birliği (KÜKAB) Örneği. Süleyman Demirel Üniversitesi İktisadi ve İdari Bilimler Fakültesi Dergisi, 15(1).

Zen, I. S., Subramaniam, D., Sulaiman, H., Omar, W., Salim, M. R. (2016). Institutionalize waste minimization governance towards campus sustainability: A case study of Green Office initiatives in Universiti Teknologi Malaysia. Journal of Cleaner Production, 135, 1407-1422.

Zülfikar, H. (2013). İstanbul İlindeki Üniversite Öğrencilerinin Katı Atıklara İlişkin Algı ve Davranışları Üzerine Ölçüm ve Analizler. Sosyal Siyaset Konferansları Dergisi, (61-74), 61-74. 